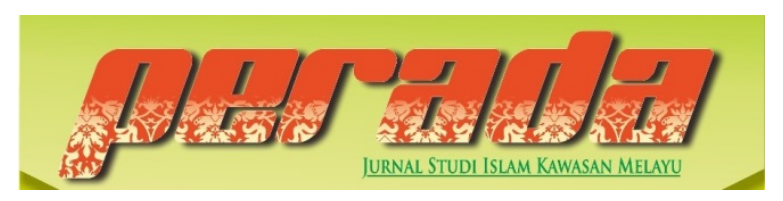

Perada: Jurnal Studi Islam Kawasan Melayu

ISSN 2656-7202 (P) ISSN 2655-6626 (0)

Volume 3 Nomor 2, Juli-Desember 2020

DOI: https://doi.org/10.35961/perada.v3i2.220

\title{
KONSEPTUALISASI MODERASI BERAGAMA SEBAGAI LANGKAH PREVENTIF TERHADAP PENANGANAN RADIKALISME DI INDONESIA
}

\author{
Ahmad Iffan \\ Universitas Bung Hatta Padang \\ alisthick@gmail.com \\ Muhammad Ridho \\ Universitas Islam Negeri Imam Bonjol \\ ridhonur@gmail.com \\ Asrizal Saiin \\ STAIN Sultan Abdurrahman Kepulauan Riau \\ asrizal@stainkepri.ac.id
}

\begin{abstract}
ABSTRAK
Tulisan ini bertujuan untuk memberikan konsepsi moderasi beragama sebagai langkah preventif dalam penanggulangan radikalisme di Indonesia. Karena tanpa melakukan konseptualiasi moderasi keagamaan yang benar akan berdampak terhadap pemikiran masyarakat yang memiliki fanatisme buta terhadap suatu pemahaman agama, oleh karena demikian hal ini akan melahirkan tindakan tindakan anarkisme yang berakhir dengan melakukan tindakan kriminal. Karena radikalisme lahir dari pemikiran dangkal masyarakat terhadap merespon konflik sosial keagamaan. Metode penelitian yang digunakan adalah yuridis normative dengan sifat penelitiannya adalah deskriptif dan sumber data yang digunakan adalah data sekunder adapun Teknik penelitian pengumpulan data yang digunakan adalah teknik penelitian kepustakaan (library research). hasil dari penelitian ini akan memperkuat konseptualisasi moderasi dengan mendalami pemahaman moderasi siyasah, mdoerasi fikih dan moderasi ibadah sebagai dasar pergerakan kemoderatan.
\end{abstract}

\section{ABSTRACT}

This study aims to provide a conception of religious moderation as a preventive step in tackling radicalism in Indonesia. Because without the correct conceptualization of religious moderation it will have an impact on the thinking of people who have blind fanaticism towards a religious understanding, therefore this will give birth to acts of anarchism that end in committing crimes. 
Because radicalism is born from the shallow thinking of society in responding to socio-religious conflicts. The research method used is juridical normative with the nature of the research is descriptive and the source of the data used is secondary data. The data collection research technique used is the library research technique. The results of this study will strengthen the conceptualization of moderation by deepening the understanding of siyasa moderation, fiqh moderation and moderation of worship as the basis for moderation movements.

Keywords: Religious Moderation, Preventive Measures, Radicalism 


\section{PENDAHULUAN}

Agama di Indonesia telah menjadi satu kesatuan dengan Negara karena berbagai unsur dan aspek kenegaraan diwarnai dengan hal hal keagamaan. Konsepsi ini merupakan bukti bahwa keberadaan Negara ini tidak terlepas dari sejarah bangsa Indonesia yang telah melahirkan Negara Kesatuan Republik Indonesia, bahkan pihak yang telah memerdekakan Indonesia secara keseluruhan merupakan pemuka agama dan aktor kemerdekaan yang memiliki tingkat religiusitas tinggi. Persebaran pemahaman keagamaan di Indonesia memerlukan langkah antisipatif terhadap penafsiran yang extreme dari suatu norma agama, karena pada dasarnya tidak ada satupun agama yang menganjurkan untuk melakukan tindakan tindakan kesewenangan hingga bersifat ekstrimisme. Kelembutan, kebersahajaan dan perdamaian merupakan ajaran pokok semua agama tanpa memilah ras dan golongan. Adapun orang orang yang melaksanakan tindakan buruk dengan dalih keagamaan merupakan kesalahan pemaha-man yang keliru, bahkan tidak jarang kesalah-pemahaman ini berbentuk sebuah organisasi aliran kiri yang melakukan tindakan tindakan pelanggaran hukum.

Dalam masyarakat Indonesia yang multibudaya, etnis, suku bangsa dan beragam kepercayaan agama, maka sikap keber-agamaan yang ekslusif seperti hanya mengakui kebenaran hanya milik sepihak agama, tentu dapat mengakibatkan gesekan antar kelompok kepercayaan agama. Berbagai konflik keagamaan yang terjadi di Indonesia, umumnya di awali dengan adanya sikap keberagamaan yang ekslusif antar agama, serta adanya persaingan yang kompetitif antar kelompok agama dengan tujuan untuk meraih dukungan masa tanpa dilandasi sikap toleran, karena keeklusifan antar agama menggunakan kekuatannya untuk meraih kemenangan sehingga memicu konflik keagamaan. ${ }^{1}$ Banyaknya budaya dan keberagaman bukanlah sebuah alasan untuk melakukan ketidak sepakatan terhadap sebuah persatuan karena Indonesia telah lahir dari sebuah bangsa yang berbeda etnis, suku dan budaya menjadi sebuah Negara kesatuan dengan banyaknya perbedaan.

Karena keberagaman ini maka perlu adanya kerpercayaan dan keyakinan seperti konsepsi keagamaan yang merupakan pedoman hidup yang berkeadilan dalam menghadapi konflik kehidupan dan kemasya-rakatan, persepektif keagamaan telah menjadi cara pandang dan pedoman yang dijadikan solusi untuk urusan dunia dan akhirat. Hal ini sesuai dengan tujuan entitas sebuah agama yaitu diturunkan ke dunia ini agar menjadi tuntunan dan pedoman hidup, norma agama diturunkan ke bumi untuk menjadi solusi dari berbagai konflik kehidupan, baik dalam skala mikro maupun makro, ruang lingkup keluarga (privat) maupun level negara (publik). ${ }^{2}$ Memer-hatikan dan mengetahui pengertian moderasi agama merupakan langkah awal untuk memahami keberbedaan.

Moderasi beragama merupakan suatu pemahaman yang diambil dari norma dan aturan keagamaan kemudian ditesrapkan secara adil dan berimbang tanpa memahami suatu teks dengan cara yang berlebih lebihan. Karena di Indonesia tidak sedikit yang melakukan tindakan kekerasan kepada seseorang apabila tidak satu pemahaman dengannya dan organisasi yang diyakininya adalah benar. Pemikiran seperti inilah yang membawa ketidaksetabilan terhadap eko-nomi, politik hingga keamanan. Bahkan dengan zaman yang serba canggih dan modern dapat

1 Agus Akhmadi, 'MODERASI
BERAGAMA DALAM
INDERAGAMAN
INDONESIA RELIGIOUS MODERATION IN
${ }^{2}$ Ibid, hlm. 50


menyebarkan informasi dengan cepat tanpa ada batasan waktu, hal inipun akan membawa dampak yang kurang produktif karena belum ada alat filterisasi informasi di jejaring internet yang efektif, maka merupakan hal yang wajar ketika sebuah pemahaman ekstrimisme dapat berkembang dengan pesat dan mempunyai masa yang besar.

Badan Litbang dan Diklat Kementerian Agama RI memberikan pengertian bahwa moderasi beragama adalah jalan tengah yang dipilih dalam sebuah keputusan dan kepemahaman, sebagaimana moderator yang mempunyai sifat untuk tidak memihak kepada salah satu pihak yang berdiskusi dan bersifat adil kepada semua pihak yang terlibat. Moderasi ini juga diartikan sebagai "sesuatu yang terbaik" seperti dalam situasi yang diharuskan untuk memilih salah satu yang terburuk ataupun yang terbaik. ${ }^{3}$ Seseorang yang mengambil jalan dan posisi di tengah dari beberapa pilihan dan posisi yang ditawarkan dinamakan "orang yang moderat" yaitu orang orang yang menerapkan prinsip moderasi beragama dalam menajalankan dan memahami aturan keagamaan.

Dalam ajaran agam Islam mengena konsep larangan untuk tidak berlebih lebihan dalam sesuatu hal sebagaimana yang disebutkan dalam QS. Al-'An`am [6] : 141

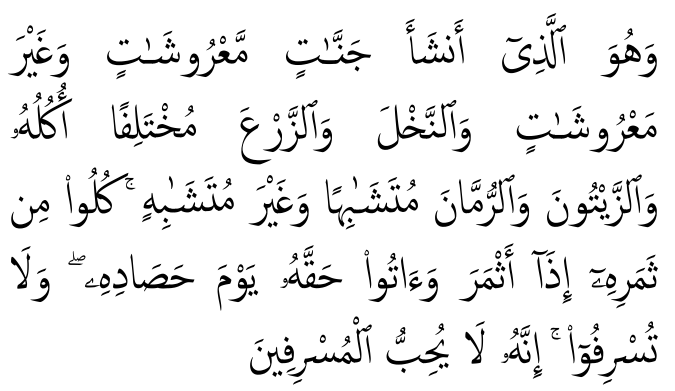

3 Tim Penyusun Kementerian Agama RI, Tanya Jawab Moderasi Beragama (Jakarta Pusat: Badan Litbang dan Diklat Kementerian Agama RI, 2019).
"Dan Dialah yang menjadikan kebun-kebun yang berjunjung dan yang tidak berjunjung, pohon korma, tanam-tanaman yang bermacammacam buabnya, zaitun dan delima yang serupa (bentuk dan warnanya) dan tidak sama (rasanya). Makanlah dari buabnya (yang bermacam-macam itu) bila dia berbuah, dan tunaikanlah haknya di bari memetik hasilnya (dengan disedekabkan kepada fakir miskin); dan janganlah kamu berlebib-lebihan. Sesunggubnya Allah tidak menyukai orang yang berlebib-lebiban."

Ayat di atas memberikan gambaran bahwa suatu hal tidaklah boleh dilakukan dan direspon dengan cara yang berlebih lebihan, salah satu pertimbangannya adalah dapat mengakibatkan suatu hati manusia menjadi lalai dan berpengaruh terhadap ketidak seimbangan akal dan fikiran. Sesuatu yang dapat mengganggu hati dan akal fikiran merupakan hal yang wajib untuk dijauhi dan ditinggalkan, bahkan tidak hanya dapat merugikan personality orang melakukan tetapi juga berdampak terhadap orang orang yang berada di lingkungan keluarga dan pekerjaan.

Konflik sosial yang terjadi di masyarakat seperti melakukan penistaan agama terhadap agama tertentu, melakukan pengrusakan terhadap rumah ibadah agama lain hingga ujaran kebencian terhadap agama lain di berbagai platform media elektronik dan media cetak. Semua hal ini berawal dari kegagalan pemahaman keagamaan terhadap kondisi dan sosial masyarakat itu sendiri yang dilakukan oleh orang orang dengan kelompoknya yang beraliran garis keras seperti tidak adanya peluang untuk melakukan diskusi dikarenakan berbeda keyakinan, hal ini ditambah dengan Islam sebagai agama dengan umat terbanyak di Indonesia, ${ }^{4}$

${ }^{4}$ Yunus and Arhanuddin Salim, 'Eksistensi Moderasi Islam dalam Kurikulum Pembelajaran PAI di SMA', Al-Tadzkiyyah: Jurnal Pendidikan Islam, 
maka ekstrimisme dengan prilaku radikalisme lahir dari pandangan pandangan tidak bias menerima terhadap kebenaran dari pihak lain yang berbeda dengannya.

Salah satu contoh pendangan yang tidak mampu untuk melakukan pemahaman moderasi beragama adalah ketika seorang pemeluk agama mengafirkan saudaranya sesama pemeluk agama yang sama hanya gara-gara mereka berbeda dalam paham keagamaan, padahal hanya Tuhan yang Maha Tahu apakah seseorang sudah masuk kategori kafir atau tidak. Seseorang yang bersembahyang terus-menerus dari pagi hingga malam tanpa mempedulikan problem sosial di sekitarnya bisa disebut berlebihan dalam beragama. ${ }^{5} \mathrm{Hal}$ ini berlaku juga terhada hinaan dan perlakukan tidak baik terhadap pemahaman agama lain yang pada tataran norma memiliki perbedaan.

Konsep kemoderatan dalam pilihan ekstrimisme yaitu tidak menjalankan agama secara berlebihan dan juga tindak berlebihan dalam menganggap mudah aturan agama. Karena seharusnya setia manusia tidak boleh mengagungkan teksteks keagamaan dengan cara fanatisme tanpa menghiraukan akal dan logika, juga tidak berlebihan terhadap keagungan akal sehingga mengabaikan norma norma yang terdapat dalam teks. Oleh karena itu keberadaan moderasi beragama bertujuan untuk menjadi solusi tengah terhadap dua kutub ekstrem dalam beragama, seharusnya setiap manusia haruslah kembali pada esensialitas suatu ajaran agama, yaitu memanusiakan manusia. ${ }^{6}$ Ekstrimisme yang dihasilkan dari ketidak moderatan akan membawa suatu pehaman kepada konsep Radikalisme, karena Radikalisme dalam agama (Islam) akan menjadi bagian

\begin{tabular}{l} 
9.2 (2019), 181 \\
<https:// doi.org/10.24042/atjpi.v9i2.3622>. \\
\multicolumn{2}{l}{${ }^{5}$ Ibid, hlm. 4} \\
${ }^{6}$ Ibid, hlm. 6
\end{tabular}

tak terpisahkan dari perubahan sosial yang demikian cepat dan keras. Sementara dipihak lainnya, sekularisasi dan rasionalisme menjadi sesuatu yang tidak mungkin pula untuk ditolak kehadirannya oleh umat beragama. Dua hal yang saling bertolak belakang akhirnya menjadi lahan tersubur untuk munculnya konflik kepentingan yang sama sama mengajukan alternatif dalam menapaki hidup. ${ }^{7}$ Pilihan pilihan ini merupakan sunnatullah (ketetapan Allah) yang tidak bias dihindari setiap fase kehidupan.

Umat beragama harus mempunyai langkah antisipatif terhadap pemahaman agama yang tidak benar dan telah tersebar di Indonesia. Salah satu langkah ini adalah dengan menggunakan prinsip moderasi beragama dalam menghadapi keberagaman pemahaman terhadap norma dan aturan agama. Oleh karena itu ini merupakan alasan peneliti untuk mengkaji terkait konsepsi moderasi agama sebagai langkah prefentif terhadap penanganan radikalisme di Indonesia. Penelitian ini menggunakan bersifat deskriptif dengan pendekatan normatif untuk membedah beberapa konsep tentang moderasi dalam Islam.

\section{MODERASI BERAGAMA DAN REKONTRUKSI PEMAHAMAN KEAGAMAAN}

Moderasi merupakan istilah kata yang dalam bahasa arab dikenal dengan alwasathiyah yang berasal dari kata wasath. Ulama kharismatik Ibnu Asyur memberikan pengertian bahwa wasath memiliki dua arti, yaitu : ${ }^{8}$ pertama, secara bahasa adalah suatu posisi yang berada di tengah tanpa memihak salah satu pihak. Kedua, perspektif terminologi bahwa

\footnotetext{
7 Qodir, Zuly, Radikalisme Agama Di Indonesia Pertautan Ideologi Politik Kontemporer Dan Kekuasaan (Yogyakarta: Pustaka Pelajar, 2014).

8 Ari Wibowo, 'Kampanye Moderasi Beragama di Facebook: Bentuk dan Strategi Pesan', 19.
} 
moderasi merupakan nilai nilai Islam yang terbentuk dari pemikiran yang baik dan tidak berlebihan akan hal sesuatu.

Moderasi dengan konsepsi jalan tengah merupakan salah satu jalur untuk menggapai keseimbangan nasional dalam segi keamanan sosial masyarakat, hal ini mempertimbangkan banyaknya konflik kecil ditengah masyarakat yang berasal dari ketidakpemahaman sosial dan keeklusifan keagamaan yang berdampak terhadap tindakan tindakan anarkisme atas nama agama. Pemerintah selalu mengambil peran penting dalam hal menanggulangi poros poros pergerakan oraganisasi masyarakat terutama mengarah kepada gerakan gerakan anarkisme dan penghasutan publik. Salah satu alasan fundamental dari pemerintah atas keputusan keputusan dalam mengkooptasi sebuah organisasi dengan berbagai pertimbangan atas nama Negara yaitu menjaga stabilitas, mulai dari stabilitas agama, ekonomi, keamanan hingga stabilitas politik.

Pertumbuhan Negara Republik Indonesia selalu diwarnai dengan berbagai konflik internal seperti anarksime keagama-an yang mencederai keberagamaan dan pemahaman pemahaman radikalisme di tengah masyarakat. konsepsi radikalisme hingga perbuatan terorisme selalu mengatasnamakan agama disetiap perbuatan mereka. Hingga saat ini, pesatnya pergolakan radikalisme masih terus bermunculan dan melakukan berbagai aksi diberbagai wilayah, bahkan konsepsi readikalisme ini telah tersebar di lembaga lembaga pendidikan. Berbagai aksi radikalisme dan penyebaran-nya disebabkan oleh faktor doktrin agama yang ekstrem, sosial, ekonomi, politik dan sebagainya. Bergai aksi radikalisme tersebut telah melanggar dan mencederai pancasila sebagai falsafah dan ideologi Negara dan Bangsa Indonesia, yang mana setiap aksi tersebut selalu memperjuangkan atas nama perjuangan konsep khilafah Islamiyah. Hal ini dikarenaka mereka lebih berpedoman kepada 'fikih saja' yang menilai segala sesuatunya hitam-putih, halal-haram, dan cenderung hanya dua sisi. Kemudian dalam prakteknya, biasanya perilaku golongan pemahaman ini seringa melakukan justifikasi sepert mengkafirkafirkan, dan bahkan membunuh yang lain.'

Moderasi agama di Indonesia telah dan atau akan diterapkan di berbagai institusi ataupun komunitas komunitas agama dan sosial, seperti sekolah dan perguruan tinggi, bahkan telah banyak penelitian terkait pentingnya membentuk konsepsi moderasi beragama di Indonesia seperti penelitian oleh Mimun dan Mohammad Qosim bahwa ada tiga alasan menadasar pentingnya konsepsi moderat di institusi pendidikan yaitu : terdapatnya ancaman paham radikal yang akhir-akhir ini menyasar kalangan perguruan tinggi, baik unsur mahasiswa, dosen, maupun tenaga kependidikan. Lima tahun yang lalu, konsentrasi penyebaran paham Islam radikal hanya mengandalkan perguruan tinggi umum, dua tahun terakhir justru mulai masuk ke perguruan tinggiperguruan tinggi keagamaan Islam, adanya kondisi sosio-politik yang dalam kurun waktu sepuluh tahun tarakhir cenderung menjadikan isu agama sebagai jualan utamanya, sehingga tidak perduli apakah isu tersebut sesuai dengan yang dikehendaki oleh teks agama atau justru sebaliknya, targetnya adalah meningkatkan electoral kelompok-kelompok yang sedang berkon-testasi dalam pilkades, pilkada, maupun pemilihan presiden. Isu agama menjadi sangat seksi untuk dilontarkan mengingat masyarakat Indonesia mayoritas

9 Hasyim, Nanang Mizwar, 'Tasawuf Dan Internalisasi Moderasi Beragama Dalam Menghadapi Problematika Bangsa', Jurnal Analisis, Volume XI Nomor 01 (2011). 
penganut agama dan kepercayaan yang masih sangat sensitive dengan isu sentiment agama. ${ }^{10}$

Kemudian pendidikan tinggi keaga-maan Islam harus berperan aktif dan kongkrit dalam memelihara dan mempertahankan Negara Kesatuan Republik Indonesia, yang saat ini dibayang-bayangi perpecahan antara umat beragama dan antar umat beragama, khususnya umat beragama Islam. ${ }^{11}$ Pemahaman tentang moderasi beragama harus dipahami dari aspek kontekstual dan secara tekstual, artinya bahwa penerapan moderasi dalam beragama di Indonesia yang tidak hanya dengan Indonesia yang dimoderatkan, tetapi cara mengkonsepsi pemahaman dalam beragama yang harus moderat karena mempertim-bangkan Indonesia memiliki banyak kultur, budaya dan adatistiadat. ${ }^{12}$ Konsep ini dapat juga ditujukan kepada makna Islam moderat atau yang dimaksud juga Islam Wasathiyyah, berasal dari dua kata yaitu Islam dan "wasathiyyah". Islam sebagaimana diartikan sebagai agama yang penuh dengan keberkahan dan toleransi, dan agama yang dibawa oleh Nabi Muhammad Saw. Islam merupakan agama mayoritas yang ada di Indonesia dengan penduduk terbanyak di dunia saat ini. ${ }^{13}$

Dalam realitas kehidupan beragama di Indonesia. Agama Islam dominan memiliki pandangan yang berperilaku ekstrem (fanatik) dalam pemahaman dan pengalaman beragama yang dikenal dengan kelompok ekstrem. ${ }^{14}$

10 Maimun, Mohammad Qosim, Moderasi Islam Di Indonesia (Yogyakarta: Lkis, 2019).

${ }^{11}$ Ibid, hlm. 152

12 Mohamad Fahri and Ahmad Zainuri, 'Moderasi Beragama di Indonesia', 25.2 (2019), 6.

${ }^{13}$ Mohammad Fahri, dkk, hlm. 96

14 Priyantoro Widodo and Karnawati Karnawati, 'Moderasi Agama dan Pemahaman Radikalisme di Indonesia', PASCA: Jurnal Teologi dan Pendidikan Agama Kristen, 15.2 (2019), 9-14 $<$ https://doi.org/10.46494/psc.v15i2.61>.
Pada tahap penerapan-nya, perwujudan moderat atau jalan tengah dalam Islam dapat diklasifikasikan menjadi empat wilayah pembahasan, yaitu: ${ }^{15}$

1. Kosep Moderat dalam persoalan akidah.

2. Kosep Moderat dalam persoalan ibadah.

3. Kosep Moderat dalam persoalan perangai dan budi pekerti

4. Kosep Moderat dalam persoalan tasyri' (pembentukan syariat)

Sikap ekstrimisme masyarakat dalam persoalan agam sudah ada sejak dahulu dimulainya ajaran Islam, seperti ceria kaum khawarij yang mengkafirkan orang orang yang tidak sepemahaman dengan mereka. ${ }^{16}$ Terutama kepada pemuda yang menjadi estafet kepemimpinan bangsa, dengan sikap ekstrimisme maka perbuatan intoleran akan dilakukan oleh orang yang tidak memahami dari dampak tersebut, beberapa faktor yang menjadikan perilaku intoleran dilakukan seperti krisis identittas, ketidak kontrolan institusi pendidikan, dan lain-lain. ${ }^{17}$ Oleh karena itu konsepsi moderasi dalam Islam memiliki aspek yang selalu membawa perubahan dan perbaikan terhadap berbagai persoalan kehidupan, sebagaimana aspek moderasi dalam Islampun mengajarkan prinsip prinsip dasar yang harus dipedomani, seperti $:^{18}$

1. Tawasuth: merupakan sikap yang tidak pada pihak fundamentalis dan tidak

\footnotetext{
${ }^{15}$ Mohammad Fahri, dkk, hlm. 97

16 Iffati Zamimah, 'MODERATISME ISLAM DALAM KONTEKS KEINDONESIAAN', 16.

17 Elma Haryani, 'Pendidikan Moderasi Beragama Untuk Generasi Milenia: Studi Kasus Lone Wolf' Pada Anak di Medan', EDUKASI: Jurnal Penelitian Pendidikan Agama dan Keagamaan, 18.2 (2020) <https://doi.org/10.32729/edukasi.v18i2.710>.

18 Karim, Hamdi Abdul, 'Implementasi Moderasi Pendidikan Islam Rahmatallil 'Alamin Dengan Nilai-Nilai Islam', Ri'ayah, Vol. 4 No. 01 (2019).
} 
juga pada pihak liberalis.

2. Tawazun: seseorang yang memiliki kemampuan menyeimbangi kehiudpan yaitu memberi dan melaksanakan hak dan kewajiban sebagaimana mestinya.

3. I'tidal: melaksanakan sesuai dengan proporsionalitas.

4. Tasamub: bersikap toleransi dalam berbagai perbedaan dan keberagaman.

5. Musawah: bersikap untuk emansipasi manusia, artinya bersikap dan melakukan konsepsi memanusiakan manusia.

6. Syura: memiliki konsepsi musyawarah dalam menggali keputusan.

7. Islab: melakukan perdamaian diberbagai konflik kemasayarakatan.

8. Awlawiyah: mampu untuk melakukan perbandingan skala prioritas.

9. Tathawur Wa Ibtikar. melakukan berbagai inovasi sesuai dengan perkembangan zaman.

10. Tahaddhur: berkarakter akblakul karimah.

Prinsip prinsip di atas merupakan prinsip dasar dalam mengkonsep moderasi Islam terhadap kemoderasian keagamaan. Yang ke 10 prinsip ini dapat berkembang dan memperbaharui berbagai teori dan kaidah dasar dari konsep moderasi. Salah satu model perkembangan moderasi beragama di Indonesia dapat diklasifikasikan kepada tiga hal, yaitu moderasi siyasah, moderasi ibadah dan moderasi fikih. Tiga hal ini merupakan persoalan mendasar di masyakarat yang sering terjadi pergeseran pemahaman dan berakibat terhadap tinda-kan ekstrimisme. Agama Islam mempunyai kaidah dasar bahwa "segala hal adalah boleh kecuali telah ada aturan atas suatu larangan" maka apapun konsep pemahaman yang tersebar di Indonesia merupakan sebuauh kebenaran apabila tidak ada aturan yang melanggar akan hal tersebut, tetapi yang menjadi persoalan utama adalah tidak mempunyai dasar yang kuat atas suatu argumentasi dan norma ketika akan menafsirkan sesautu hal.

\section{Moderasi Siyasah}

Banyak ahli memberikan pengertian terkait konsep siyasah, dalam Wikipedia siyasah diartikan sebagai salah satu kata yang terdapat peristilahannya dalam Bahasa Arab yang dihubungka dengan otoritas hubungan politik. Dalam sumber literatur sebelum Islam bahwa siyasah lebih diartikan kepada manajemen urusan dalam suatu negara. Hal ini membawa perbuahan terhadap penggunaan makna dalam konsepsi kata Bahasa Arab. Pengertiannya merujuk pada kajian-kajian politik, seperti al-Siyasah al-Madaniyyah karya al-Farabi, siyasah merujuk pada cabang ilmu filsafat yang mendalami ilmu seni berpolitik. Dalam fiqih Islam Sunni, siyasah terdapat pada kata siyasah syar'iyyah, yang berarti suatu negera yang mempunyai pemerintahan berdasarkan hukum Islam (syariah). Kata tersebut merujuk kepada doktrin atau dimensi politis dari hukum Islam, yang sudah ada sejak abad pertengahan, tujuannya adalah untuk mengharmonisasikan hukum Islam dengan tuntutan dalam urusan politik. ${ }^{19}$ Harmonisasi inipun telah dilakukan oleh berbagai expert untuk melakukan asimilasi hukum Islam kepada sistem hukum nasional.

Masyarakat sering melupakan sifat kenerimaan dan kelogoan hati dalam sebuah kompetisi, sedangkan makna moderasi lain adalah dapat menerima dengan tenang tanpa ada perlawanan yang juga hal ini merupakan salah satu indikator konsep "Islam Rabmatan lil 'Alamin", artinya apapun persoalan muamalah di kehidupan haruslah membawa kemanfaatan untuk diri dan orang lain,

\footnotetext{
19

Wikipedia, https://id.wikipedia.org/wiki/Siyasah, diakses pada tanggal 15 Desember 2020. Dapat dilihat juga pada Encyclopaedia of Islam, Second Edition
} 
ketika tidak mampu untuk menerapkan ini maka sama halnya belum mampu untuk bersikap moderat. Konsepsi Moderatisme dalam ajaran Islam yaitu haruslah sesuai dengan prinsip prinsip Rahmatan lil 'Alamin, oleh karena itu sangat diperlukan sikap anti kekerasan ditengah kalangan masyarakat, karena tanpa ada yang meulai maka sulit untuk dapat memahami perbedaan yang mungkin sering terjadi, mengutamakan kontekstualisasi dalam memaknai ayat ayat Allah SWT, menggunakan istinbath untuk menerapkan hukum modern serta menggunakan pendekatan ilmu sains dan teknologi untuk memberikan justifikasi dan mengatasi dinamika persoalan sosial di masyarakat Indonesia. seharusnya perbedaan sikap dan pilihan menjadi keragaman kehidupan sosial yang menjadi bagian dari masyarakat yang madani. Keberadaan Islam yang moderat cukup menjadi penjaga terhadap konsistensi Islam yang telah dibawa oleh Rasulullah Saw. Untuk mengembalikan citra Islam yang sebenarnya, maka diperlukan moderasi agar penganut lain dapat merasakan kebenaran ajaran Islam yang Rabmatan lil 'Alamin.$^{20}$ Karena prinsip moderasi pada dasarnya bukan untuk orang orang yang sadar akan manfaat dan fungsinya tetapi juga diperuntukkan kepada masyarakat yang tidak terlibat dalam moderasipun mendapatkan manfaat tersebut.

Salah satu persoalan yang sering dihadapi adalah ketika mengikuti Pemilu (Pemilihan Umum), setiap kontestan yang ikut berkompetisi sering melakukan mauver politik yang terkadang tidak membawa kemanfaatan untuk khalayak ramai. Tidak jarang pihak pihak tertentu melakukan perlakukan fitnah dan kecurangan ketia pra ataupun pasca kontestasi, masyarakat yang ikut mendukungpun menjadi ikut serta dalam pertikaian tersebut bahkan yang menjadi

${ }^{20}$ Mohammad Fahri, dkk, hlm. 97 aktor dalam konflik fisik adalah masyarakat itu sendiri. Seharusnya dalam pemikiran domokrai yang matang adalah memiliki prinsip siap menang dan siap kalah dalam berbagai kompetisi terutama perihal politik.

Konsep Islam dalam perihal pemilu adalah dianjurkan selama mambawa kemaslahatan untuk umat, sedangkan konsep moderasi siyasah dalam sebuah kontestasi politik juga memberikan arti siap kalah dan siap memang dengan ikhlash, karena dalam moderasi siyasah juga menggunakan prinsip di sebuah norma yang mengatakan bahwa "sesuatu yang dibenci bukanlah hal yang buruk dan segala yang disukai belum tentu sebauh kebaikan" karena penting setiap umat beragama meyakini bahwa segala sesuatu merupakan sunnatullah dari Allah SWT yang telah mengatur dan merumuskan setiap peristiwa yang ada.

\section{Moderasi Ibadah}

Selain moderasi siyasah yang memberikan aturan dasar dalam bersikap moderat terhadap sebuah sistem pemerintahan, maka perlu juga untuk mengkaji hal yang sering dihadapi dan dipersoalkan oleh masyarakat terkait penerapan penerapan ibadah seperti perihal menzaharkan basmalah, melaksanakan qunut, hingga tata cara iabadah wajib lainnya. Melihat setiap alasan mempunyai sumber dan hukum yang berdalil, seperti hukum membawa basmalah atau tidak, beberapa ulama berpendapat wajib dan beberapa ulama tidak diharuskan bahkan perbedaan ini juga terdapat pada mengeraskan membaca basmalah dan menyembunyikan pembacaan basmalah.

Seperti pengikut imam Syafii yang dikenal sebagai Syafi'iyah mengemukakan pendapat bahwa wajib hukumnya untuk membaca basmalah dengan dalil adalah bagian dari Al Fatihah. Maka dengan 
hukum wajib yang melekat pada membaca Al Fatihah juga menjadi wajib pembacaaan basmalah yang mengikutinya, salah satu dalilnya adalah :

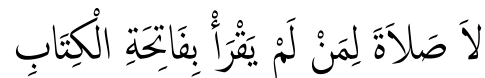

"tidak ada salat bagi orang yang tidake membaca Faatihatul Kitaab" (HR. Al Bukhari 756, Muslim 394)

Di antara para golongan salaf yang juga memiliki pemikiran demikian adalah Al Kisa-i, 'Ashim bin An Nujud, Abdullah bin Katsir, dan yang lainnya. Golongan Syafi'iyyah juga berkeyakinan wajib untuk membaca Al Fatihah sebelum qira'ah setiap awal surat dari Al Qur'an dalam salat. Sementara pengikut imam hanafi yang disebut sebagai Hanafiyah berpendapat bahwasanya membaca basmalah bukan bagian dari al-Fatihah, adapun dalil argumentasi mereka adalah bahwa membaca basmalah ketika dalam salat hukumnya adalah sunnah sebelum membaca al-Fatihah di setiap rakaat. Disunnahkannya untuk membaca basmalah sebelum surah Al-Fatihah karena dalam rangka tabarruk dengan basmalah. Adapun pembacaan selain Al-Fatihah tidak disunnahkan. Namun berbeda dengan pemikiran pengikut imam Malik yaitu Malikiyyah berpendapat tidak disunnahkan untuk membaca basmalah sebelum qira'ah setelah al-Fatihah, sedangkan menurut Hanabilah bahwa membaca basmalab adalah sunnah hukumnya baik sebelum al-Fatihah maupun sebelum qira'ah. Dan Malikiyyah membolehkan tasmiyah sebelum al-Fatihah ataupun sebelum qira'ah. ${ }^{21}$

Adapun pendapat yang masyhur adalah dari Malikiyyah, yang juga

\footnotetext{
21 Hukum Basmalah, muslim.or.id https:// muslim.or.id/19744-hukum-basmalahdalam-shalat.html diakses pada 15 Desember 2020 pukul 08.30 WIB
}

berpendapat basmalah bukan bagian dari Al Fatihah, mereka mengatakan bahwa membaca basmalah sebelum Al Fatihah ataupun qira'ah hukumnya makruh. Mereka berdalil dengan hadits Anas bin Malik:

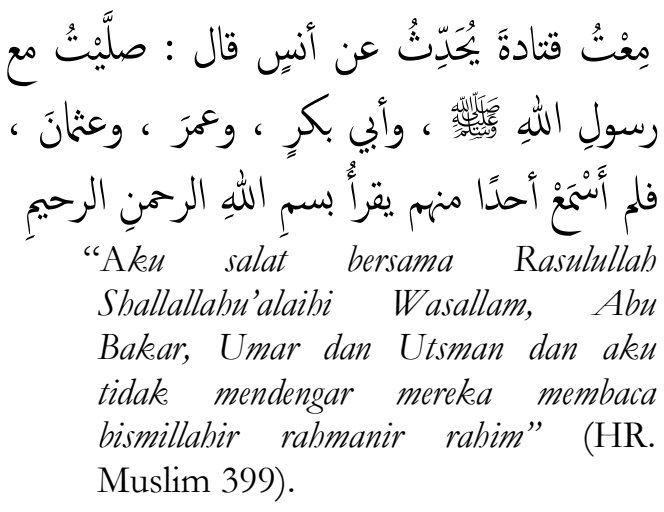

Namun ada riwayat dari Imam Malik bahwa beliau berpendapat diperbolehkan membaca basmalah, dan riwayat lain dari Malikiyyah yang mengatakan hukumnya wajib. Kesimpulannya, persoalan khilafiyah ini berporos pada masalah apakah basmalah itu termasuk al-Fatihah ataukah tidak dan apakah ia termasuk bagian dari setiap surat atau tidak. Maka dalam hal membaca basmalah atau tidak membaca basmalah perkaranya longgar. ${ }^{22}$ Dalam hal pembacaan basmalah secara dikeraskan memiliki argumentasi dalil seperti perkataan $\mathrm{KH}$ Muhyiddin Abdusshomad ${ }^{23}$ bahwa al-Fatihah itu terdiri dari ayat yang dibaca secara berulang-ulang pada tiap-tiap raka'at salat. Dan ayat yang pertama adalah basmalah. Dalam sebuah hadits disebutkan:

${ }^{22}$ Ibid. $\mathrm{KH}$ Muhyiddin Abdusshomad, Apakah Wajib Mengeraskan Bacaan 'Basmalah' dalam Shalat

Berjamaah?,https://islam.nu.or.id/post/read/1481 2/apakah-wajibmengeraskanbacaanamp8217basmalahamp821 7dalam-shalat-berjamaah, diakses tanggal 15 Desember 2020 pada pukul 20.40 WIB. 


$$
\begin{aligned}
& \text { عَنْ أَبَيْ هُرَيْرَة قَالَ: قَالَ رَسُوْلُ اللهِهِ صَلَّى اللَُّ }
\end{aligned}
$$

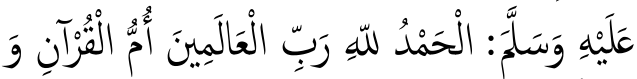

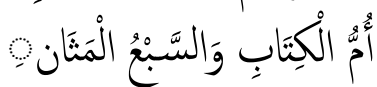

"Dari Abu Hurairah beliau berkata, Rasalullab SAW bersabda, "albamdu lillahi rabbil 'alamin" merupakan induk Al-Qur'an, pokoknya al-Kitab, serta Surat as-Sab'ul Matsani." (HR Abu Dawud)

Berdasarkan dalil ini, Imam Syafi'i RA mengatakan bahwa basmalah merupakan bagian dari ayat yang tujuh dalam surat al-Fatihah. Jika ditinggalkan, baik seluruhnya maupun sebagian, maka raka' at salatnya tidak sah.

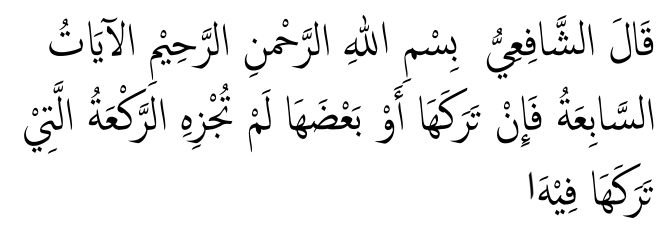

"Imam Syafi'f $\mathrm{R} A$ mengatakan babwa basmalah merupakan tujub ayat dari surat al-Fatilah. Apabila ditinggalkan atau tidak dibaca sebagian ayatnya, maka raka'atnya tidak cukup."

Oleh karena merupakan bagian dari surat al-Fatihah, maka basmalah ini juga dianjurkan untuk dikeraskan ketika seseorang membaca al-Fatihah dalam salatnya, sesuai dengan Hadits Nabi SAW:

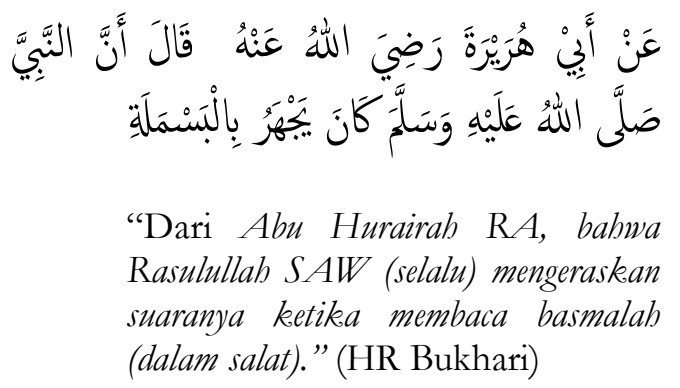

Menjelaskan hadits ini, 'Ali Nayif Biqa'i dalam tabqiq kitab Idza Shabha al-
Hadits Fabuwa Madŗhabi karangan Syeikh as--Subki menjelaskan: "Ibn Khuzaimah berkata dalam kitab Mushannaf-nya menya-takan, pendapat yang menyatakan sunnah mengeraskan basmalah merupakan pendapat yang benar. Ada hadits dari Nabi SAW dengan sanad yang muttashil (urutan perawi hadfts yang sampai langsung kepada Nabi Muhanzmad SAW), tidak diragukan, serta tidak ada keraguan dari para ahli hadfts tentang shahih serta muttashil-nya sanad hadfts ini.

Kemdian Ibn Khuzaimah berkata, telah jelas dan telah terbukti bahwa Nabi SAW (dalam hadits tersebut) mengeraskan bacaan basmalah dalam salat." (Ma'na Qawl al-Imam al-Muththalibi Izda Shahha al-Hadits Fahuwa Madzhabi, hal 161) Dengan demikian dapat kita ketahui bahwa basmalah merupakan sebagian surat dari al-Fatihah, sehingga harus dibaca manakala membaca al-Fatihah dalam salat. Dan juga basmalah disunnahkan untuk dikeraskan dalam salat jahriyyah atau salat yang disunnahkan untuk mengeraskan suara yakni maghrib, isya' dan subuh dan beberapa salat sunnah berjamaah yang dikerjakan pada malam hari. Sunnah artinya lebih utama dikerjakan tapi tidak sampai pada hukum wajib. Kesunnahan mengeraskan bacaan basmalah ini sebagaimana sunnahnya mengeraskan keseluruhan al-Fatihah dalam salat jahriyyah tersebut. ${ }^{24}$

Maka pandangan moderasi ibadah adalah tidak menjustifikasih salah dan benar terhadap salah satu pendapat diatas, karena pada dasarnya setiap argumentasi memiliki alasan hukum dan dalil yang kuat. Memilih dengan tidak memberikan kesalahan adalah sifat moderasi beragama dan menerapkan keduanya dalam ibadah adalah sikap moderasi ibadah.

\section{Moderasi Fikih}

Konsep fikih dan ibadah merupakan 
dua dari satu kesatuan yang tidak dapat dipisahkan karena dasar dasar pelaksanakan ibadah adalah konsep dan prinsip prinsip yang berada didalam fikih. Dalam konsep fikih moderasi dikenal dengan istilah wasatho yaitu wasit yang bediri di tengah yang tidak memihak salah satu pihak, dan wasit inipun bukan hanya sekedar mengambil posisi tanpa piker panjang karena pilihan ditengah adalah unsur yang dipilih karena ilmu yang diperoleh. Tanpa ilmu maka pilihan tengahpun akan membawa kemudhorotan terhadap para pihak. Misal persoalan yang merupakan kesalahan pemikiran adalah ketika beribadah merasa semakin banyak rakaat adalah sesuatu hal yang baik dengan memper-kirakan akan memperolah banyak pahala padahal pemikiran ini adalah sesat dan tidak dibenarkan oleh agaman.

Karena penerapan fikih bukan menerapkan konsep "Menurut saya, dll" tetapi berdasarkan dalil dan ketentuan yang berlaku di dalam Al Quran dan Al Hadits. Pemahaman tanpa dasar yang jelas akan bermuara kepada kesesatan yang salah. Salah satu kisah yang mengaharuskan untuk bersikap moderat adalah kisah ketika zaman nabi Muhammad SAW. Ketika rasulullah memerintahkan Bani Khuraizah untuk pergi ke suatu tempat maka ketika di perjalan terjadi ikhtilaf diantara mereka yang memperdebatkan apakah harus salat ashar atau jama takhir ketika telah sampai di tujuan dengan ebrbagai pertimbangan. Pada akhir keputusan terbagilah kelompok mereka yang melaksanakan salat dan yang melanjutkan perjalanan. Setiba di tujuan dan bertemu Rasulullah maka rasulullah memebrikan keputusan yang bijak untuk tidak menyalahkan kedua pilihan tersebut, maka dalam ha ini Rasulullah telah bersikap moderat yang dapat mempersatukan umat Islam.

Islam moderat dengan prinsip moderatisme beragama merupakan solusi yang dapat dipilih untuk menjadikan keadaan bangsa dan negara Indonesia menjadi lebih kondusif dari berbagai persoalan anarkisme yang bersumber dari pemahaman pemahaman radikalisme. Islam moderat merupakan jalan tengah dari dua pemikiran yang berlawanan yaitu fundamentalis dan liberalis. ${ }^{25}$ Langkah langkah dan jalur yang mengarah ke radkalisme haruslah ditumpas dan dihilangkan dengan memperkuat prinsip Islam rahmatalilalamin dalam bingkai konsep moderasi beragama. Oleh karena itu haruslah agama sebagai topik utama dan dikaitkan dengan radikalisme khususnya di Indonesia, kita agaknya tidak bisa lagi menempatkan agama hanya sekedar sebagai "norma" dan pemahaman atas norma yang tersedia dalam kitab suci para nabi dan dianut para umatnya. Kita harus pula menempatkan agama dalam perspektif sebagai agensi-agensi perubahan sosial yang penting kehadirannya, juga kita harus menempatkan posisi agama dalam wilayah yang harus turut bertanggung jawab dalam memberikan jawaban atas adanya krisis nasional bahkan krisis internasional tentang kemanusiaan dan peradaban, yang menimbulkan pertempuran dan kekerasan massal. ${ }^{26}$

Moderasi agama haruslah difahami sebagai bentuk komitmen ${ }^{27}$ masyarakat untuk menanggulangi persoalan perbedaan konsep fikih yang keseluruhan pendapat adalah benar dengan dalil dalil yang mendukung secara lengkap. Salah satu bentuk kesungguhan para pemuka agama Islam dalam memperkuat moderasi keagamaan di Indonesia adalah dengan menciptakan konsep Islam Nusantara yang

25 Ahmad Agis Mubarok and Diaz Gandara Rustam, 'ISLAM NUSANTARA: MODERASI ISLAM DI INDONESIA', Journal of Islamic Studies and Humanities, 2018, 16.

${ }^{26}$ Zuly Qodir, hlm. 235

27 Khotimah, Husnul, Internalisasi Moderasi Beragama Dalam Kurikulum Pesantren (Institut Agama Islam Negeri Madura). 
lahir dari keberagamaan budaya dan adat istiadat dan kemudian saling mempengaruhi antara norma agama dan kebudayaan masyarakat, oleh karena itu dibentuknya konsepsi Islam Nusantara adalah salah satu wujud moderasi Islam di Nusantara. ${ }^{28}$ Konsepsi moderasi agama Islam adalah menjadikan Islam sebagai wadah kemoderatan keagamaaan, salah satu ciri dalam konsep moderasi Islam adalah menentukan amal prioritas, hal ini disebut juga sebagai fikih prioritas. Kajian ini pun merupakan salah satu hal penting ketika akan menerapkan moderasi agama dalam keberagaman, karena dengan menentukan prioritas fikih akan meminimalisir konflik yang terjadi dalam masyarakat.

Pemahaman keagamaan seperti kepercayaaan Islam yang tidak menerapkan moderasi beragama akan berujung pada konsep Islam radikal yaitu menggunakan cara cara kekerasan agar tujuan dan setiap keinginan tercapai, pada konsep ini merupakan berawal dari ketidak pemahaman mengenai konsep Islam yang kaffah. Hal ini dapat dilihat bahwa agama Islam dan agama manapun tidak membenarkan sikap sikap radikalisme sebagaima dijelaskan dalam sumber hukum Islam al-Qur'an bahwa dilarang melakukan kegiatan kegiatan yang merugikan diri sendiri dan manusia lainnya. ${ }^{29}$ Agama sering dijadikan sebagai tameng atau bentuk pengakuan tindakan radikalisme untuk menutupi suatu kejahatan, ${ }^{30}$ karena hanya konsepsi agama yang terdapat pilihan untuk merasa benar atau memiliki otoritas untuk masuk surge, hal ini dipengaruhi oleh timbal balik

${ }^{28}$ Mubarok and Rustam.

29 Syaikhu Rozi, 'PENDIDIKAN MODERASI ISlam Kh. Asep Saifuddin Chalim; Mencegah Radikalisme Agama Dan Mewujudkan Masyarakat Madani Indonesia', 18.

30 Khamdan, Muh, Bina Damai Terorisme (Kudus: Parist, 2015). terhadap pembalasan sejarah masa lalu. ${ }^{31}$ Dengan sikap seperti ini maka sering yang melakukan tindakan radikalisme hanya sebagai perilaku kesalahan dan bukan sebagai kejahatan.

\section{KESIMPULAN}

Moderasi agama haruslah dijalan sungguh sungguh dan didukung oleh berbagai elmen masyarakat mulai dari lembaga masyarakat hingga institusi pendidikan perguruan tingga dan sekolah sekolah umum maupun keagamaan. Pemahaman moderasi agama yang benar akan mampu untuk menstabilkan diri dalam mehamai suatu teks norma agama tanpa melakukan hal yang berlebihan dan mubazir. Hal yang utama harus difahami oleh masyarakat adalah konsep moderasi siyasah dalam menghadapi persoalan Negara dan pemerintahan, kemudian moderasi fikih untuk perihal pelaksanan agama dari segi hukumnya dan hal ibadah yang sering sebagai alasan untuk suatu kaum agama melakukan pertikaian public antar anggota masyarakat. Pemikiran moderat keagamaan tidak hanya akan membawa dampak pisitif terhadap seseorang pemeluk agama tersebut tetapi juga berdampak kepada umat dan pergerakan oraganisasi keagamaan. Maka dengan konsepsi moderasi agama yang kuat maka akan mampu untuk lahirnya pemikiran pemikiran ekstrimisme yang akan bermuara kepada radikalisme.[]

DAFTAR PUSTAKA

Akhmadi, Agus, 'Moderasi Beragama Dalam Keragaman Indonesia Religious Moderation In Indonesia's Diversity', 13.2 (2019), 11

Jurgensmayer, Mark, Terror In The Mind Of God: The Global Rise Of Religious Violence (California: University Of California Press, 2001). 
Ali, Zainuddin, Metode Penelitian Hukum (Jakarta: Sinar Grafika, 2010)

Fahri, Mohamad, And Ahmad Zainuri, 'Moderasi Beragama Di Indonesia', 25.2 (2019), 6

Haryani, Elma, 'Pendidikan Moderasi Beragama Untuk Generasi Milenia: Studi Kasus Lone Wolf" Pada Anak Di Medan', EDUKASI: Jurnal Penelitian Pendidikan Agama Dan Keagamaan, $18.2 \quad$ (2020) $<$ Https://Doi.Org/10.32729/Eduk asi.V18i2.710>

Hasyim, Nanang Mizwar, 'Tasawuf Dan Internalisasi Moderasi Beragama Dalam Menghadapi Problematika Bangsa', Jurnal Analisis, Volume XI Nomor 01 (2011)

Irianto, Sulistyowati Dan Sidharta, Metode Penelitian Hukum: Kontelasi Dan Refleksi (Jakarta: Yayasan Pustaka Obor Indonesia, 2011)

Jurgensmayer, Mark, Terror In The Mind Of God: The Global Rise Of Religious Violence (California: University Of California Press, 2001)

Karim, Hamdi Abdul, 'Implementasi Moderasi Pendidikan Islam Rahmatallil 'Alamin Dengan Nilai-Nilai Islam', Ri'ayah, Vol. 4 No. 01 (2019)

Khamdan, Muh, Bina Damai Terorisme (Kudus: Parist, 2015)

Khotimah, Husnul, Internalisasi Moderasi Beragama Dalam Kurikulum Pesantren (Institut Agama Islam Negeri Madura)

Maimun, Mohammad Qosim, Moderasi Islam Di Indonesia (Yogyakarta: Lkis, 2019)
Marzuki, Peter Mahmud, Penelitian Hukum, Edisi Revisi, (Jakarta: Kencana, 2013)

Moleong, Lexy J, Metodologi Penelitian Kualitatif (Bandung: PT Remaja Rosdakarya, 2007)

Mubarok, Ahmad Agis, And Diaz Gandara Rustam, 'Islam Nusantara: Moderasi Islam Di Indonesia', Journal of Islamic Studies And Humanities, 2018, 16

Qodir, Zuly, Radikalisme Agama Di Indonesia Pertautan Ideologi Politik Kontemporer Dan Kekuasaan (Yogyakarta: Pustaka Pelajar, 2014)

Rozi, Syaikhu, 'Pendidikan Moderasi Islam Kh. Asep Saifuddin Chalim; Mencegah Radikalisme Agama Dan Mewujudkan Masyarakat Madani Indonesia', 18

Suratman \& Philips Dillah, Metode Penelitian Hukum (Bandung: Alfabeta, 2013)

Tim Penyusun Kementerian Agama RI, Tanya Jawab Moderasi Beragama (Jakarta Pusat: Badan Litbang Dan Diklat Kementerian Agama RI, 2019)

Wibowo, Ari, 'Kampanye Moderasi Beragama Di Facebook: Bentuk Dan Strategi Pesan', 19

Widodo, Priyantoro, And Karnawati Karnawati, 'Moderasi Agama Dan Pemahaman Radikalisme Di Indonesia', PASCA: Jurnal Teologi Dan Pendidikan Agama Kristen, 15.2 (2019), 9-14 $<$ Https://Doi.Org/10.46494/Psc.V 15i2.61>

Yunus, Yunus, And Arhanuddin Salim, 'Eksistensi Moderasi Islam Dalam Kurikulum Pembelajaran PAI Di SMA', Al-Tadzkiyyah: Jurnal Pendidikan Islam, 9.2 
(2019),

181

$<$ Https://Doi.Org/10.24042/Atjpi. V9i2.3622>

Zamimah, Iffati, 'Moderatisme Islam Dalam Konteks Keindonesiaan', 16

Wikipedia,

Https://Id.Wikipedia.Org/Wiki/Si yasah, Diakses Pada Tanggal 15

Desember 2020. Dapat Dilihat

Juga Pada Encyclopaedia Of

Islam, Second Edition 